\title{
Histology and Origin of Somatic Embryos Derived from Anthurium andraeanum Linden ex André Lamina
}

\author{
Tracie K. Matsumoto ${ }^{1,3}$, David T. Webb ${ }^{2}$, and Adelheid R. Kuehnle ${ }^{1,4}$ \\ University of Hawaii at Manoa, 3190 Maile Way, Honolulu, HI 96822-2279
}

Additional index words. Araceae, tissue culture, somatic embryogenesis, microtechnique

\begin{abstract}
Histological analysis of somatic embryos derived from in vitro-grown lamina of Anthurium andraeanumshowed bipolarity with the presence of shoot and root poles connected by procambium. Vascular connections between the explant and somatic embryos were not observed. Storage of proteins, starch and raphides as well as a suspensor-like structure and an epidermis were observed in the somatic embryos. Origin of the somatic embryos was from a proembryonic cell complex or possibly from a single cell by direct embryogenesis. Both modes of somatic embryogenesis arose from the mesophyll.
\end{abstract}

Anthurium cut flowers and blooming potted plants are important commodities in the United States and in the Netherlands. Micropropagation using callus culture, bud culture with enhanced axillary branching, and somatic embryogenesis provides the means for rapid clonal propagation of Anthurium (Geier, 1990; Matsumoto and Kuehnle, 1996). Of these methods, somatic embryogenesis is considered the best for large-scale clonal propagation of many crops. It is also the most desirable for gene transfer systems since development of somatic embryos from single cells aids in selection of transformed totipotent cells and minimizes production of chimeras. Geier (1982) reported somatic embryogenesis for $A$. scherzerianum Schott. spadix cultures and Kuehnle et al. (1992) reported the same for $A$. andraeanum in vitro-grown lamina. Both systems yielded somatic embryos that germinated into single or multiple plantlets.

Histological studies are important for the confirmation of somatic embryogenesis. Determining the cell types from which somatic embryos arise is also of interest, especially in gene transfer systems. Colby et al. (1991) showed that transformation-competent cells were different from regeneration-competent cells of Vitis vinifera $\mathrm{L}$. leaves and petioles. Thus, transformed cells did not regenerate plants. Anthurium is amenable to transformation by Agrobacterium tumefaciens (Kuehnle and Sugii, 1991; Kuehnle and Chen, 1994). A system was being developed in this lab for the production of genetically engineered Anthurium via somatic embryogenesis from in vitro leaves (Chen, 1993). Hence, the purpose of this study was to determine histologically the origin of somatic embryos from in vitro-grown $A$. andraeanum lamina and to identify the cell layer within the lamina that gives rise to somatic embryos.

\section{Materials and Methods}

In vitro-grown lamina of $A$. andraeanum 'Anuenue' and

\footnotetext{
Received for publication 11 Sept. 1995. Accepted for publication 2 Jan. 1996. Journal series no. 4140 of the Hawaii Institute of Tropical Agriculture and Human Resources. We thank Nellie Sugii for aid in photography. The cost of publishing this paper was defrayed in part by the payment of page charges. Under postal regulations, this paper therefore must be hereby marked advertisement solely to indicate this fact.

'Dept. of Horticulture.

${ }^{2}$ Dept. of Botany.

${ }^{3}$ Current address: Dept. of Horticulture, Purdue Univ., West Lafayette, IN 47907.

${ }^{4}$ To whom reprint requests should be addressed.
}

'Toyama Peach' were harvested from plantlets subcultured monthly on multiplication medium (Kunisaki, 1980). Lamina were placed on somatic embryogenesis media B and D according to Kuehnle et al. (1992). Basal medium contained half-strength MS (Murashige and Skoog, 1962) macronutrients, full-strength MS micronutrients, $100 \mathrm{mg} \cdot$ liter $^{-1}$ myo-inositol, $25 \mathrm{mg} \cdot$ liter $^{-1}$ NaFeEDTA, MS

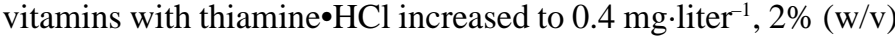
sucrose, $1 \%(w / v)$ glucose and $0.18 \%(w / v)$ Gelrite (Sigma Chem. Co., St. Louis). Medium B contained $1.0 \mathrm{~mm}$ 2,4-dichlorophenoxyacetic acid (2,4-D) and $0.15 \mathrm{~mm}$ kinetin (kin) (Sigma Chem. Co., St. Louis) and medium D contained $0.5 \mathrm{~mm} 2,4-\mathrm{D}$ and 0.15 mmkin (Kuehnle et al., 1992). Media were autoclaved for 20 min $(121 \mathrm{C}, 15 \mathrm{psi})$ and dispensed into $100 \times 15$-mm plastic petri plates $(20 \mathrm{ml} /$ plate $)$. Cultures were kept in complete darkness at $23 \mathrm{C}$ and subcultured to fresh medium at 4-week intervals.

Somatic embryos and any adjoining portion of an explant were excised and placed in a modified Karnovsky (1965) fixative containing $2 \%$ glutaraldehyde and $2.5 \%$ paraformaldehyde in a $0.05 \mathrm{~m}$ sodium cacodylate buffer. Following a brief vacuum treatment at $3.2 \mathrm{psi}$, specimens were fixed overnight at $5 \mathrm{C}$, rinsed three times with cacodylate buffer and dehydrated in ethanol with $10 \%$ increments. For infiltration, $3 \mathrm{ml} 100 \%$ ethyl alcohol and $1 \mathrm{ml}$ glycol methacrylate Historesin (Leica Inc., Deerfield, Ill.) infiltration solution were added to the specimen; additional infiltration solution (1-ml aliquots) was added every other day. After 1 week, the Historesin-alcohol mixture was replaced by $100 \%$ Historesin infiltration solution. The solution was changed every other day until the tissue appeared translucent. Inverted Beem (Ted Pella, Reading, Calif.) capsules with a small hole in the pointed end were used for embedding so that explants would lie flat against the lid for proper orientation. Adding resin through the small hole minimized atmospheric contact to aid polymerization of Historesin. Polymerization proceeded under vacuum to further exclude oxygen.

Glass knives were made with an LKB Knifemaker. Trimmed blocks were sectioned at $4.8 \mathrm{~mm}$ with a Sorval Porter-Blum MT2B ultra-microtome. Sections were floated on distilled water and heated on a slide warmer at 40C. Slides were stained with periodic acid-Schiff (PAS) reagent for carbohydrates and counterstained with napthol-blue-black for proteins (Feder and O'Brien, 1968). A total of 8 different specimens containing many somatic embryos at different stages of development was harvested from 'Anuenue' and 'Toyama Peach' lamina explants 10 weeks after culture initiation. Sections were examined with a Zeiss compound microscope and photographed with a Zeiss M35W camera. 


\section{Results and Discussion}

Formation of somatic embryos occurred from 6 to 13 weeks, with 'Anuenue' generally responding earlier than 'Toyama Peach'. Macroscopic somatic embryos appeared after 10 weeks of culture and were morphologically similar to those described for other genotypes by Kuehnle et al. (1992). Responsive lamina showed various developmental stages at this time point. Of eighteen total explants, two showed initial swelling, five had globular protrusions at the cut surface, four presented multiple somatic embryos, and seven had multiple somatic embryos with secondary embryos. Our histological observations are based on $>24$ individual somatic embryos, including those at early stages of embryogenesis.

Longitudinal sections of a fully mature Anthurium somatic embryo showed clear bipolarity, with both a shoot and root pole as well as a continuous procambium and an epidermis (Fig. 1A). Procambium connected the shoot and root meristems and tracheary elements were evident. The above features fulfill the anatomical requirements of a true somatic embryo.

Isodiametric cells comprising the epidermis bordered the somatic embryo (Fig. 1B). Calcium oxalate crystals (raphides) characteristic of A. andraeanum zygotic embryos (Matsumoto, 1994) were abundant (Fig. 1B). Geier (1982) used the presence of epidermis and raphides to confirm somatic embryogenesis in $A$. scherzerianum spadix cultures. In addition, a cotyledon is present with anatomy and starch storage similar to that of the zygotic embryo (Matsumoto, 1994).

Development of the root pole (Fig. 1C) appeared delayed relative to the shoot pole. Cells of the root apex were clearly in earlier stages of organization than those of the shoot pole. Similar observations were made for geranium, sorghum, and sugarcane (Botti and Vasil, 1983; Ho and Vasil, 1983; Wilson et al., 1994). In addition, somatic embryos in our study were not subcultured to maturation and conversion medium (Kuehnle et al., 1992). Thus, in Anthurium sustained exposure to 2,4-D and kinetin may have inhibited root development as in carrot cell cultures (Halperin and Jensen, 1967).

In addition to the above, single cell origin is a criterion defining somatic embryogenesis (Haccius, 1978). We observed two possible modes of embryo initiation. In many cases, individual globular embryos arose by apparent direct embryogenesis from the mesophyll and were hypothesized to be of single cell origin. In other cases, somatic embryos arose from a mass of meristematic cells similar to those described by Haccius (1978) as a proembryonic cell complex. Single cell origin is difficult to determine since the fate of the cell cannot be determined once it is fixed. In the absence of time course data, the origin of Anthurium lamina somatic embryos remains speculative.

Fig. 1. Longitudinal sections of representative Anthurium andraeanum Linden ex Andre' somatic embryos. (A) Overview with shoot and root poles connected by procambium. $\mathrm{sa}=$ shoot meristem, $\mathrm{p}=$ procambium, $\mathrm{r}$ $=$ root meristem, $\mathrm{lp}=$ leaf primordium, $\mathrm{c}=$ cotyledon. Bar $=400 \mu \mathrm{m}$. (B) Shoot pole in enlarged view of $\mathbf{A}$ showing internal meristematic activity and raphides bordered by an organized epidermis. ep = epidermis, $\mathrm{sa}$ $=$ shoot meristem, $\mathrm{lp}=$ leaf primordium, $\mathrm{ra}=$ raphides, $\mathrm{p}=$ procambium. Bar $=180 \mu \mathrm{m}$. (C) Root pole with distinct protoderm from a different somatic embryo. $r=$ root meristem, $\mathrm{d}=$ protoderm. Bar $=125 \mu \mathrm{m}$.
The first evidence of Anthurium somatic embryo development that we observed, in those lamina with initial swelling, involved a single mesophyll cell that divided medially followed by two longitudinal divisions to produce terminal cells and a basal cell (Fig. 2A). This type of division is typical of angiosperm zygotic embryogenesis (West and Harada, 1993) and also resembles the early stages of promeristemoids (Flinn et al., 1988). Presence of a basal or micropylar vacuole in the zygote is associated with the establishment of polarity and the basal cells observed by us were highly vacuolated. The vacuolated basal cell gives rise to the suspensor-like structure while the more densely cytoplasmic terminal cells form the embryo proper (Mansfield and Briarty, 1991). Developmental sequences of somatic embryogenesis were similar to those of zygotic embryogenesis in Anthurium, including division of the basal cells to produce the suspensor-like structure (Matsumoto, 1994) (Fig. 2B). Similar observations have been described in many other somatic embryogenesis systems (Dos Santos et al., 1983; Kim and Janick, 1989; Quinn et al., 1989; Wilson et al., 1994), including Fig. 19 of the classic work in carrot by Halperin and Jensen (1967).

Subsequent cell divisions were most frequent in the terminal cells. This produced bipolar somatic embryos (Fig. 2B). At this stage somatic embryos were readily distinguished from the surrounding mesophyll cells by their darkly staining, proteinaceous cytoplasm and large starch grains (Fig. 2C). In all specimens with these early stages of development, intermediate structures between those of Fig. 2A and Fig. 2B, and Fig. 2B and Fig. 2C, were noted.

Globular somatic embryos are shown in Fig. 2D. The outer layer of the somatic embryo was composed of small cells with dense cytoplasm and small starch grains; the inner cells were highly vacuolated with large starch grains. An indentation with meristematic cells (Fig. 2D, right) resembled the lateral notch marking the primordial shoot apex (Kuehnle et al., 1992). Starch and protein bodies similar to those of zygotic embryos were observed within the somatic embryos (Matsumoto, 1994). Raphides
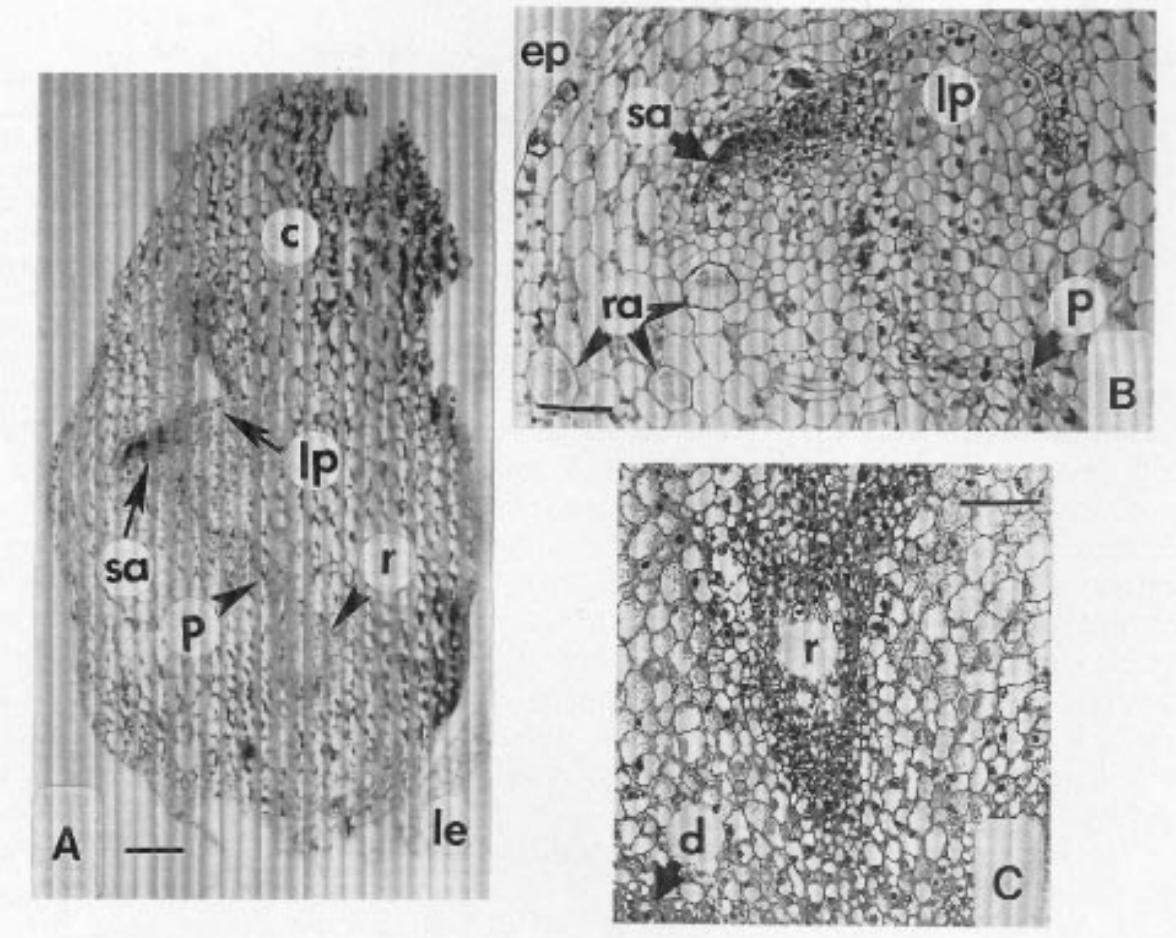
were also present between the inner and outer layer of somatic embryos, indicating cytodifferentiation typical of zygotic embryos.

Centrally located meristematic cells (Fig. $2 \mathrm{E})$ were apparent in sections of all globular somatic embryos observed and proved to form procambium in more developed somatic embryos, similar to zygotic embryos. Densely stained meristematic cells evident at the periphery of the globular somatic embryo comprised the protoderm. These produced a uniform layer of more vacuolate, rectangular cells that developed into the epidermis. The mesophyll circumscribed, and was clearly distinct from, the developing somatic embryo, with no evidence of vascular connection (Fig. 2E). Absence of a vascular connection is a further criterion for somatic embryogenesis (Haccius, 1978). In addition, a suspensor-like structure was evident at the base of somatic embryos (Fig. $2 \mathrm{E}$ and F). This structure is virtually identical to the suspensor in the Anthurium zygotic embryo in that it consists of two tiers of densely cytoplasmic cells of similar size with tight association to the embryo proper (Matsumoto, 1994).

Multiple somatic embryos were also observed in the explants and were connected by clusters of densely cytoplasmic cells with prominent nuclei (Fig 2D). These cell clusters lacked features present in globular somatic embryos, namely highly vacuolated inner cells with predominant starch grains, and are hy-
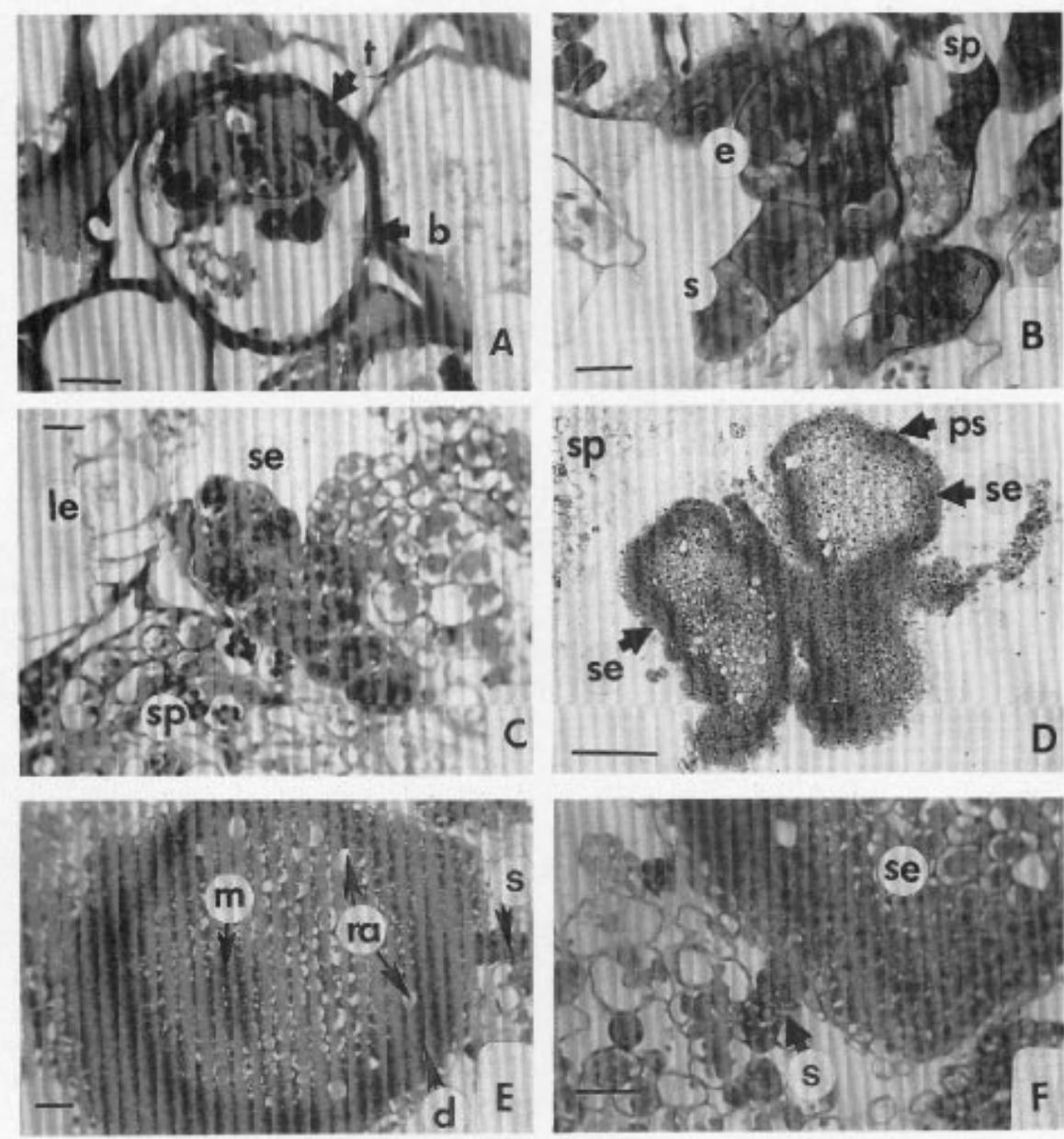
pothesized to be proembryonic cell complexes (Haccius, 1978). Haccius (1978) described the

latter structure as functionally similar to the suspensor of the zygotic embryo and unicellular in origin.

Determination of the cellular origin of somatic embryos is difficult since fixation permanently halts further development of a specimen. As in our study, other authors have deduced the cellular origin by observations of different developmental stages of somatic embryogenesis (Conger et al., 1987; Eapen et al., 1989; Gray and Conger, 1985; Kim and Janick, 1989; McWilliam et al., 1974; Michaux-Ferriere et al., 1992; Polito et al., 1989; Trigiano et al., 1989; Wilson et al., 1994).

To identify the tissue that underwent somatic embryogenesis, cross sections of embryogenic explants were compared with unresponsive explants also on media B and D (Fig. 3). Unresponsive explants consisted of two layers of isodiametric cells, comprising the adaxial and abaxial epidermis, and spongy parenchyma cells, comprising the mesophyll (Fig. 3A). In contrast, a responsive lamina such as that forming the somatic embryo pictured in Fig. 2B contained small densely cytoplasmic cells with darkly stained nuclei characteristic of meristematic cells during early somatic embryogenesis (Fig. 3B) (Halperin, 1970; Kim and Janick, 1989). These structures were readily distinguished at this time from degraded epidermal cells and from surrounding disorganized or senescing mesophyll. All somatic embryos appeared to originate from the mesophyll. No other tissue was observed to form somatic embryos on the media tested.

This study confirmed the formation of somatic embryos in $A$. andraeanum using a protocol established for other genotypes by Kuehnle et al. (1992). Our study upholds these structures to be

Fig. 2. Development of representative Anthurium andraeanum somatic embryos. (A) Cell within mesophyll that has undergone transverse division to form a terminal ( $\mathrm{t}$ ) and basal (b) cell and two longitudinal divisions of the terminal cell; considered a promeristemoid. Bar $=25 \mu \mathrm{m}$. (B) Somatic embryo comprised of characteristic cells with densely stained cytoplasm, large starch grains and prominent nuclei. $\mathrm{sp}=$ spongy parenchyma, $\mathrm{s}=$ suspensor-like structure, $\mathrm{e}=$ embryo. Bar $=25 \mu \mathrm{m}$. (C) Somatic embryo that has penetrated the epidermis of the lamina explant. $\mathrm{se}=$ somatic embryo, $\mathrm{sp}=$ spongy parenchyma, le = lamina epidermis. Bar $=50 \mu \mathrm{m}$. (D) Globular somatic embryos that arose from a proembryonic cell complex. se = somatic embryo, $\mathrm{sp}=$ spongy parenchyma, $\mathrm{ps}$ $=$ primordial shoot apex. Bar $=100 \mu \mathrm{m}$. (E) Typical later stage of a globular somatic embryo and suspensor-like structure within the lamina. Note the internal meristematic region and surrounding highly vacuolated cells with large starch grains and raphides, and the peripheral intact protodermis and cytoplasmically dense cells with small starch grains. $\mathrm{ra}=$ raphides, $\mathrm{d}=$ protodermis, $\mathrm{s}=$ suspensorlike structure, $\mathrm{m}=$ meristematic center. $\mathrm{Bar}=25 \mu \mathrm{m}$. (F) Higher magnification of the suspensor-like structure in $\mathbf{E}$ showing cell size, arrangement and attachment similar to the Anthurium zygotic suspensor. se $=$ somatic embryo, $\mathrm{s}=$ suspensorlike structure. $\mathrm{Bar}=100 \mu \mathrm{m}$.

somatic embryos based on bipolarity, vascular continuity of the shoot and root meristems, vascular autonomy from the explant, and presence of epidermis, raphides, starch, and storage of protein. The latter four traits were previously reported for somatic and zygotic embryos of $A$. scherzerianum (Geier, 1982).

Observations in this study support the hypothesis that somatic embryos of $A$. andraeanum originate within the mesophyll via direct embryogenesis. There is also evidence for a proembryonic cell complex in the mesophyll potentially forming embryos. The presence of the proembryonic cell complex may account for 


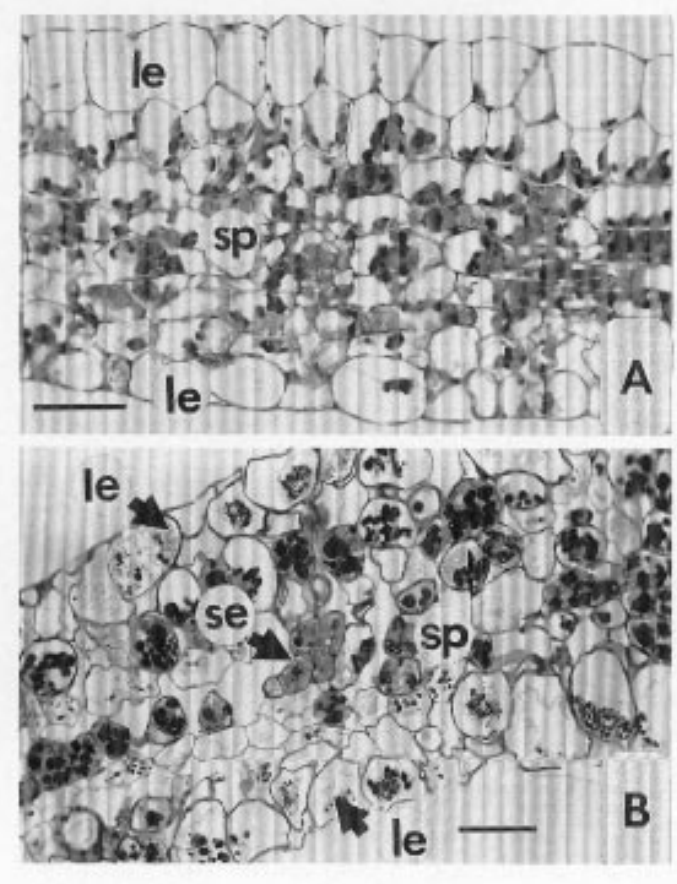

Fig. 3. Cross sectional view of an lamina explants at week 10 of culture. (A) An unresponsive lamina explant. le = lamina epidermis, $\mathrm{sp}=$ spongy parenchyma Bar $=100 \mu \mathrm{m}$. (B) Somatic embryo shown in Fig. 2B arising from the mesophyll of a responsive lamina. $\mathrm{se}=$ somatic embryo, $\mathrm{le}=$ lamina epidermis, $\mathrm{sp}=$ spongy parenchyma. $\mathrm{Bar}=200 \mu \mathrm{m}$.

reports of both isolated and tightly clustered somatic embryos within the same explant (Geier, 1982; Kuehnle et al., 1992). The results of this study are encouraging for regeneration of nonchimeric transformed plants, provided gene transfer is targeted to the mesophyll and the transformed cells are those that regenerate. For absolute confirmation of somatic embryo ontogeny, a nondestructive methodology for the continuous study of embryogenesis is required.

\section{Literature Cited}

Botti, C. and I.K. Vasil. 1983. Ontogeny of somatic embryos in Pennisetum americanum. II. In cultured immature inflorescences. Can. J. Bot. 62:1629-1635.

Chen, F.C. 1993. Genetic engineering of Anthurium for bacterial disease resistance. $\mathrm{PhD}$ diss., Univ. of Hawaii at Manoa, Honolulu.

Colby, S.M., A.M. Juncosa, and C.P. Meredith. 1991. Cellular differences in Agrobacterium susceptibility and regenerative capacity restrict the development of transgenic grapevines. J. Amer. Soc. Hort. Sci. 116:356361.

Conger, B.V., F.J. Novak, R. Afze, and K. Erdelsky. 1987. Somatic embryogenesis from cultured segments of Zea mays. Plant Cell Rpt. 6:345-347.

Dos Santos, A.V.P., E.G. Cutter, and M.R. Davey. 1983. Origin and development of somatic embryos in Medicago sativa L. (alfalfa). Protoplasma 117:107-115.

Eapen, S., V. Abraham, M. Gerdemann, and O. Schieder. 1989. Direct somatic embryogenesis, plant regeneration and evaluation of plants obtained from mesophyll protoplasts of Brassica juncea. Ann. Bot. 63:369-372.

Feder, N. and T.P. O'Brien. 1968. Plant microtechnique: some principles and new methods. Amer. J. Bot. 55:123-142.

Flinn, B.S., D.T. Webb, and W. Newcomb. 1988. The role of cell clusters and promeristemoids in determination and competence for caulogenesis by Pinus strobus cotyledons in vitro. Can. J. Bot. 66:1556-1565.
Geier, T. 1982. Morphogenesis and plant regeneration from spadix fragments of Anthurium scherzerianum cultivated in vitro, p. 137-138. In: A. Fujiwara (ed.). Proc. 5th Intl. Congr. Plant Tissue Cell Cult., Jpn. Assn. Plant Tissue Cult.

Geier, T. 1990. Anthurium, p. 228-252. In: P.V. Ammirato, D.A. Evans, W.R. Sharp, and Y.P.S. Bajaj (eds.). Handbook of plant cell and tissue culture. vol. 5. McGraw-Hill, New York.

Gray, D.J. and B.V. Conger. 1985. Somatic embryo ontogeny in tissue cultures of orchardgrass, p. 49-57. In: R.R. Henke (ed.). Tissue culture in forestry and agriculture. Plenum Press, New York.

Haccius, B. 1978. Question of unicellular origin of non-zygotic embryos in callus cultures. Phytomorphology 28:74-81.

Halperin, W.A. 1970. Embryos from somatic plant cells, p. 169-191. In: H.A. Padykula (ed.). Control mechanisms in the expression of cellular phenotypes. Academic Press, New York.

Halperin, W. and W.A. Jensen. 1967. Ultrastructural changes during growth and embryogenesis in carrot cell cultures. J. Ultrastruct. Res. 18:548-443.

Ho, W.J. and I.K. Vasil. 1983. Somatic embryogenesis in sugarcane (Saccharum officinarum L.) I. The morphology and physiology of callus formation and the ontogeny of somatic embryos. Protoplasma 118:169_ 180.

Karnovsky, M.J. 1965. A formaldehyde-glutaraldehyde fixative of high osmolarity for use in electron microscopy. J. Cell. Biol. 27:137A.

Kim, Y. and J. Janick. 1989. Origin of somatic embryos in celery tissue culture. HortScience 24:671-673.

Kuehnle, A.R. and F.C. Chen. 1994. Genetic transformation in Anthurium, p. 215-225. In: Y.P.S. Bajaj (ed.). Biotechnology in agriculture and forestry. vol. 29. Springer Verlag Berlin, Heidelberg.

Kuehnle, A.R., F.C. Chen, and N. Sugii. 1992. Somatic embryogenesis and plant regeneration in Anthurium andraeanum hybrids. Plant Cell Rpt. 11:438-442.

Kuehnle, A.R. and N. Sugii. 1991. Induction of tumors in Anthurium andraeanum by Agrobacterium tumefaciens. HortScience 26:13251328.

Kunisaki, J.T. 1980. In vitro propagation of Anthurium andreanum Lind. HortScience 15:508-509.

Mansfield, S.G. and L.G. Briarty. 1991. Early embryogenesis in Arabidopsis thaliana. II. The developing embryo. Can. J. Bot. 69:461476.

Matsumoto, T.K. 1994. Aspects of zygotic and somatic embryogenesis in Anthurium. MS thesis, Univ. of Hawaii at Manoa, Honolulu.

Matsumoto, T.K. and A.R. Kuehnle. 1996. Anthurium micropropagation. In: Y.P.S. Bajaj (ed). Biotechnology in agriculture and forestry: High technology and micropropagation. Springer Verlag, New York. (In press.)

McWilliam, A.A., S.M. Smith, and H.E. Street. 1974. The origin and development of embryoids in suspension cultures of carrot (Dacus carota). Ann. Bot. 38:243-250.

Michaux-Ferriere, N., H. Grout, and M.P. Carron. 1992. Origin and ontogenesis of somatic embryos in Hevea brasiliensis (Euphorbiaceae). Amer. J. Bot. 79:174-180.

Murashige T. and F. Skoog. 1962. A revised medium for rapid growth and bioassays with tobacco tissue cultures. Physiol. Plant. 15: 151-158.

Polito, V.S., G. McGranahan, K. Pinney, and C. Leslie. 1989. Origin of somatic embryos from embryogenic cultures of walnut (Juglans regia L.); implications for Agrobacterium-mediated transformation. Plant Cell Rpt. 8:219-221.

Quinn, J., J.E. Simon, and J. Janick. 1989. Histology of zygotic and somatic embryogenesis in borage. J. Amer. Soc. Hort. Sci. 114:516520.

Trigiano, R.N., D.J. Gray, B.V. Conger, and J.K. McDaniel. 1989. Origin of direct somatic embryos from cultured leaf segments of Dactylis glomerata. Bot. Gaz. 150:72-77.

West, M.A.L. and J.J. Harada. 1993. Embryogenesis in higher plants: An overview. Plant Cell 5:1361-1369.

Wilson, D.P.M., J.A. Sullivan, A.A. Marsolais and M.J. Tsujita. 1994. Histology of somatic embryogenesis in regal geranium. J. Amer. Soc. Hort. Sci. 119:648-651. 